\title{
Cyclometallated imidazo-phenanthroline iridium complexes and their anticancer activity
}

\author{
PALAK GARG ${ }^{\mathrm{a}}$, UMASANKAR DE ${ }^{\mathrm{b}}$, NIRANJAN DEHURY ${ }^{\mathrm{a}}$, HYUNG SIK KIM ${ }^{\mathrm{b}}$ and \\ SRIKANTA PATRA ${ }^{\mathrm{a}, *}$ (D)

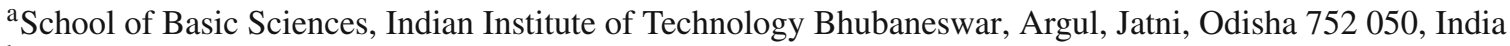 \\ ${ }^{\mathrm{b}}$ Division of Toxicology, School of Pharmacy, Sungkyunkwan University, Suwon, Gyeonggi-do, Republic of \\ Korea \\ E-mail: srikanta@iitbbs.ac.in
}

MS received 16 January 2018; revised 27 February 2018; accepted 1 March 2018; published online 25 June 2018

\begin{abstract}
Cyclometallated mononuclear iridium complexes (1-3) were synthesized using dimeric precursor $\left[(\mathrm{ppy})_{2} \mathrm{Ir}^{\mathrm{III}}(\mu-\mathrm{Cl})\right]_{2}$ and imidazo-phenanthroline-based ligands $\left(\mathbf{L}_{1}-\mathbf{L}_{3}\right)$. The complexes were characterised using various analytical techniques. The complexes exhibited spin forbidden metal-to-ligand charge transfer (MLCT) transitions at wavelengths $>300 \mathrm{~nm}$ and high energy ligand-based transition below $300 \mathrm{~nm}$. The complexes were found to be emissive and displayed emission bands at $580 \mathrm{~nm}$ upon excitation at $380 \mathrm{~nm}$ with quantum yields 0.07 with respect to standard $\left[\mathrm{Ru}(\mathrm{bpy})_{3}\right] \mathrm{Cl}_{2}$. The complexes $\mathbf{1 - 3}$ showed dose-dependent suppression of cell viability ( $\mathrm{IC}_{50}$ values $\sim 2.5 \mu \mathrm{M}$ ) towards human breast (MCF7) cancer cell line. The hydrophobicity measurements and flow cytometry analysis suggest that cellular uptake is primarily responsible for observed cytotoxicity.
\end{abstract}

Keywords. Iridium; phenanthroline; imidazole; anticancer agent.

\section{Introduction}

Organometallic complexes of iridium have received considerable attention in the field of metal-based anticancer research. This is primarily due to their inertness leading to low toxicity and lesser side effects, bioavailability and cancer cell selectivity as compared to wellknown cisplatin. ${ }^{1-3}$ In addition, iridium complexes are known to induce selective kinase inhibition property and often display non-apoptotic mode of cancer cell death which are useful for the treatment of resistant cancer. ${ }^{1,4-9}$ Moreover, the exciting luminescence properties of iridium complexes are often used as probes for understanding biological processes. In this aspect, a large number of cyclometallated iridium complexes have been developed and studied using various ligand frameworks. ${ }^{5,7,8,10-25}$ Among various ancillary ligands, pyridine-based $\mathrm{N}^{\wedge} \mathrm{N}$ chelating ligands are most promising considering their excellent coordinating ability and stability under physiological condition. ${ }^{2,4,5,14,18,20,24-28}$
Different substituents have been incorporated to $\mathrm{N}^{\wedge} \mathrm{N}$ donor-based ligands in order to tune the property and activity of the complexes. On the contrary, the use of $\mathrm{N}^{\wedge} \mathrm{N}$ donating ligands incorporating imidazo unit is limited. ${ }^{29-32}$ It is known that the imidazole unit efficiently interacts with biomolecules and display biological activity. In addition, imidazole unit provides synthetic accessibility to incorporate various donors and substituents which can help to control electronic and steric environment, required for hydrophobicity and solubility. Although there are C-substituted imidazolebased ligands and their corresponding complexes are known, N-substituted imidazole-based ligands and their corresponding complexes are limited. Considering the afore-mentioned observations, we plan to develop $\mathrm{N}$ substituted imidazo-phenanthroline-based ligands $\left(\mathbf{L}_{1}-\right.$ $\mathbf{L}_{3}$ ) and their corresponding cyclometallated iridium complexes. Different substituents (pyridine, benzyl and cyclohexyl) are incorporated at imidazole unit to study their effect on the anticancer efficacy (Chart 1).

\footnotetext{
*For correspondence

Electronic supplementary material: The online version of this article (https://doi.org/10.1007/s12039-018-1492-6) contains supplementary material, which is available to authorized users.
} 


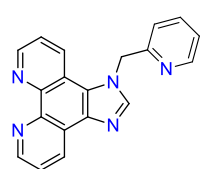

L1

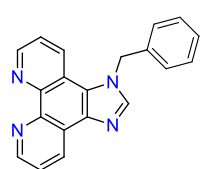

L2

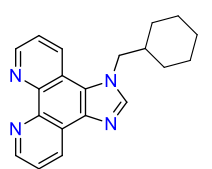

L3
Chart 1. Structure of ligands.

Herein, we report the development of cyclometallated iridium complexes $\left[(\text { ppy })_{2} \operatorname{Ir}\left(\mathbf{L}_{1}-\mathbf{L}_{3}\right)\right]$ (1-3) using ligands: 1 -(pyridin-2-ylmethyl)-1H-imidazo[4,5-f][1,10] phenanthroline $\left(\mathbf{L}_{1}\right) ;$ 1-benzyl-1H-imidazo[4,5-f][1,10] phenanthroline $\left(\mathbf{L}_{2}\right)$ and 1-(cyclohexylmethyl)-1Himidazo[4,5-f][1,10]phenanthroline) $\left(\mathbf{L}_{3}\right)$. The complexes were characterized by various analytical techniques. The anticancer activity of the complexes were tested against human breast cancer (MCF-7) cell line and their variation in anticancer activity were assayed using hydrophobicity measurement, flow cytometry analysis and fluorescence microscopy.

\section{Experimental}

\subsection{Materials}

1-H-imidazo [4,5-f][1,10]phenanthroline and the ligand $\mathbf{L}_{2}$ were synthesized according to the reported procedure with slight modification. ${ }^{33}$ The precursor complex $\left[(\mathrm{ppy})_{2} \operatorname{Ir}(\mu\right.$ $\mathrm{Cl})]_{2}$ was synthesized by following the procedure as discussed in literature. ${ }^{34}$ All the chemicals were purchased from commercial sources and used as received. Solvents were dried by conventional methods and distilled prior to use.

\subsection{Instrumentation}

Electrical conductivity of the complex solutions were checked using an OKATON PC 2700 Conductivity bridge. UV-Vis spectra were recorded using a Perkin Elmer Lambda 35 spectrophotometer. FTIR spectra were obtained using a Bruker Alpha FTIR spectrophotometer with samples prepared as $\mathrm{KBr}$ pellets. Electrospray ionisation (ESI) mass spectra were recorded on a Bruker microTOF QII high-resolution mass spectrometer. ${ }^{1} \mathrm{H}$ NMR spectra were acquired on a Bruker Avance III 400 spectrometer using DMSO- $\mathrm{d}_{6}$ as the solvent. Electrochemical measurements were carried out under dinitrogen atmosphere using a CHI 760D electrochemical analyser with $\mathrm{NEt}_{4} \mathrm{ClO}_{4}$ as the supporting electrolyte $(0.1 \mathrm{M})$, and the solute concentration was $10^{-3} \mathrm{M}$. For electrochemical measurements, a glassy carbon working electrode, $\mathrm{Pt}$ wire counter electrode and $\mathrm{Ag} / \mathrm{AgCl}$ as the reference electrode were used. The half-wave potential $E_{298 K}$ was set equal to $0.5\left(E_{\mathrm{pa}}+E_{\mathrm{pc}}\right)$, where $E_{\mathrm{pa}}$ and $E_{\mathrm{pc}}$ are anodic and cathodic cyclic voltammetric peak potentials, respectively. In this cell, $\mathrm{Fc} / \mathrm{Fc}^{+}$couple had an $E_{1 / 2}$ value of $0.26 \mathrm{~V}$. Fluorescence measurements were carried out using a Fluoromax
4P spectrofluorimeter (Horiba Jobin Mayer, USA). The quantum yield of the complexes in acetonitrile were calculated by comparing the quantum yield value of $\left[\mathrm{Ru}(\mathrm{bpy})_{3}\right] \mathrm{Cl}_{2}$ in water using the following equations. ${ }^{35}$

$$
\begin{aligned}
\Phi_{\text {complex in } \mathrm{H}_{2} \mathrm{O}=} & \Phi_{\left[\mathrm{Ru}(\text { bpy })_{3}\right] \mathrm{Cl}_{2} \text { in } \mathrm{H}_{2} \mathrm{O}} \\
\times & \times \frac{I_{\text {Complex }}}{I_{\left[\mathrm{Ru}(\text { bpy })_{3}\right] \mathrm{Cl}_{2}}} . \\
\Phi_{\text {complex in } \mathrm{CH}_{3} \mathrm{CN}=}= & \Phi_{\text {Complex in } \mathrm{H}_{2} \mathrm{O}} \\
& \times \frac{I_{\text {Complex in } \mathrm{CH}_{3} \mathrm{CN}}}{I_{\text {Complex in } \mathrm{H}_{2} \mathrm{O}}} \times \frac{R I_{\mathrm{CH}_{3} \mathrm{CN}}^{2}}{R I_{\mathrm{H}_{3} \mathrm{O}}^{2}} .
\end{aligned}
$$

Where $R I=$ refractive index of the solvent; $I=$ area under the emission band of the complex in the solvent. The emission quantum yields of the complexes in water were evaluated from the standard value of $\left[\mathrm{Ru}(\mathrm{bpy})_{3}\right] \mathrm{Cl}_{2}$ in water (0.042) using equation 1.

\subsection{Hydrophobicity measurement}

The lipophilicity of the complexes was determined by a flask-shaking method using n-octanol/water solvent system by following the reported procedure. ${ }^{36}$

\subsection{In vitro cytotoxicity assay}

Cell viability was determined using 3-(4,5-dimethylthiazol-2yl)-2,5-diphenyl-tetrazolium bromide (MTT, $5 \mathrm{mg} / \mathrm{mL}$ ). The cultures were initiated in 96-well plate after $24 \mathrm{~h}$ of preincubation with various concentrations of complexes (1-3) for $24 \mathrm{~h}$ and $48 \mathrm{~h}$. After incubation, MTT reagent was added to each well and incubated for $4 \mathrm{~h}$ at $37^{\circ} \mathrm{C}$ in dark. The supernatant was aspirated and formazan crystals were dissolved in $200 \mu \mathrm{L}$ DMSO at room temperature for $15 \mathrm{~min}$ with gentle agitation. The absorbance per well was measured at $540 \mathrm{~nm}$ using the VERSA Max (Microplate Reader).

\subsection{Flow cytometry assay}

The MCF-7 cells were treated with complexes 1-3 $(10 \mu \mathrm{M})$ for $24 \mathrm{~h}$. The total numbers of cells were harvested separately, out of which $1 \times 10^{6}$ cells were removed, washed with PBS. The fluorescence intensity of the complex treated cells was measured using Guava EasyCytePlus flow cytometer (Merck Millipore).

\subsection{Synthesis of ligands}

2.6a Synthesis of [1-(pyridin-2-ylmethyl)-1H-imidazo [4,5-f][1,10] phenanthroline] $\left(\boldsymbol{L}_{1}\right): \quad$ To $180 \mathrm{mg}$ (0.82 mmol) of 1-H-imidazo [4,5-f][1,10]phenanthroline $338.6 \mathrm{mg}(2.5 \mathrm{mmol}) \mathrm{K}_{2} \mathrm{CO}_{3}$ was added in $10 \mathrm{~mL}$ dry DMF and reaction mixture was stirred at room temperature for $30 \mathrm{~min}$. Then, to the stirred solution, $250 \mathrm{mg}(0.98$ mmol) 2-(bromomethyl)pyridine hydrobromide was added. After a reaction time of $3 \mathrm{~h}$, the solvent was removed under 
reduced pressure. The residue thus obtained was dissolved in chloroform and extracted with water. The organic phase was separated, treated with anhydrous $\mathrm{Na}_{2} \mathrm{SO}_{4}$ and dried to get pure yellow coloured ligand $\mathbf{L}_{1}$. Yield: $220 \mathrm{mg}(86 \%)$. ${ }^{1} \mathrm{H} \mathrm{NMR}\left(400 \mathrm{MHz} \mathrm{CDCl}_{3}\right.$ at $\left.298 \mathrm{~K}\right) \delta 9.20(\mathrm{dd}, J=4$, $1.8 \mathrm{~Hz}, 1 \mathrm{H}), 9.10(\mathrm{dd}, J=4,1.6 \mathrm{~Hz}, 1 \mathrm{H}), 9.05(\mathrm{dd}, J=8$, $1.8 \mathrm{~Hz}, 1 \mathrm{H}), 8.71$ (ddd, $J=4,2,1 \mathrm{~Hz}, 1 \mathrm{H}), 8.38$ (dd, $J=8$, $1.6 \mathrm{~Hz}, 1 \mathrm{H}), 8.20$ (s, 1H), 7.77 (dd, $J=8,4.4 \mathrm{~Hz}, 1 \mathrm{H}), 7.58$ $(\mathrm{td}, J=8,1.8 \mathrm{~Hz}, 1 \mathrm{H}), 7.51(\mathrm{dd}, J=8,4 \mathrm{~Hz}, 1 \mathrm{H}), 7.26(\mathrm{~m}$, $1 \mathrm{H}), 6.81(\mathrm{~d}, J=8,1 \mathrm{H}), 5.97(\mathrm{~s}, 2 \mathrm{H})$

2.6b Synthesis of 1-(cyclohexylmethyl)-1H-imidazo [4,5-f][1,10] phenanthroline $\left(\boldsymbol{L}_{3}\right)$ : The ligand $\mathbf{L}_{3}$ was prepared by following the similar procedure as for $\mathbf{L}_{1}$. Yield: $200 \mathrm{mg}(71 \%) .{ }^{1} \mathrm{H} \mathrm{NMR}\left(400 \mathrm{MHz}, \mathrm{CDCl}_{3}\right.$ at $\left.298 \mathrm{~K}\right) \delta 9.19$ $(\mathrm{m}, 2 \mathrm{H}), 9.00(\mathrm{dd}, J=8,2 \mathrm{~Hz}, 1 \mathrm{H}), 8.49(\mathrm{dd}, J=8,2 \mathrm{~Hz}$, 1H), 7.95 (s, 1H), $7.74(\mathrm{~m}, 2 \mathrm{H}), 4.42$ (d, $J=8 \mathrm{~Hz}, 2 \mathrm{H}), 2.00$ $(\mathrm{m}, 1 \mathrm{H}), 1.77(\mathrm{~m}, 5 \mathrm{H}), 1.21(\mathrm{~m}, 5 \mathrm{H})$.

\subsection{Synthesis of metal complexes}

2.7a Synthesis of $\left[\left\{(p p y)_{2} \operatorname{Ir}\right\} L_{1}\right]\left(P F_{6}\right)(1)$ : A mixture of $\left[(\mathrm{ppy})_{2} \operatorname{Ir}(\mu-\mathrm{Cl})\right]_{2}(51.4 \mathrm{mg}, 0.08 \mathrm{mmol})$ and $\mathbf{L}_{1}$ (50 mg, $0.16 \mathrm{mmol}$ ) were dissolved in $20 \mathrm{~mL} \mathrm{2-methoxy-}$ ethanol. The mixture was refluxed under $\mathrm{N}_{2}$ atmosphere for $12 \mathrm{~h}$. The solvent was then reduced to $2 \mathrm{~mL}$ under reduced pressure. A saturated aqueous $\mathrm{KPF}_{6}$ solution was added in resulted solution to yield the precipitate. The yellow coloured precipitate thus obtained was filtered off and washed thoroughly with distilled water. The crude product was purified by neutral alumina column using $\mathrm{CH}_{2} \mathrm{Cl}_{2}$ : $\mathrm{CH}_{3} \mathrm{OH}(50: 1)$ as eluent to yield pure 1. Yield: $59.6 \mathrm{mg}(38.9 \%)$. Molar conductivity $\left[\Lambda_{\mathrm{M}} /\left(\Omega^{-1} \mathrm{~cm}^{2} \mathrm{M}^{-1}\right)\right]$ in acetonitrile: 100 . A positive ion ESI mass spectrum of $\mathbf{1}$ in $\mathrm{CH}_{3} \mathrm{OH}$ exhibited signal at $m / z=811$ corresponding to $\left[\mathbf{1}-\mathrm{PF}_{6}\right]^{+}$(calculated molecular mass 811.93). ${ }^{1} \mathrm{H}$ NMR (400 MHz, DMSO-d 6 at 298K): $\delta 9.20(\mathrm{dd}, J=8.3,1.5 \mathrm{~Hz}, 1 \mathrm{H}), 8.94(\mathrm{dd}, J=8.7,1.3 \mathrm{~Hz}$, $1 \mathrm{H}), 8.87(\mathrm{~s}, 1 \mathrm{H}), 8.45$ (d, $J=4.6 \mathrm{~Hz}, 1 \mathrm{H}), 8.25$ (t, $J=8 \mathrm{~Hz}$, $2 \mathrm{H}), 8.17(\mathrm{dd}, J=5.1,1.5 \mathrm{~Hz}, 1 \mathrm{H}), 8.10(\mathrm{~m}, 2 \mathrm{H}), 7.94(\mathrm{~m}$, $3 \mathrm{H}), 7.85(\mathrm{~m}, 3 \mathrm{H}), 7.51(\mathrm{~d}, J=8 \mathrm{~Hz}, 1 \mathrm{H}), 7.46(\mathrm{~d}, J=6 \mathrm{~Hz}$, $2 \mathrm{H}), 7.31(\mathrm{dd}, J=8,4,1.1 \mathrm{~Hz}, 1 \mathrm{H}), 7.05$ (tdd, $J=7.6,6.4$, $1.2 \mathrm{~Hz}, 2 \mathrm{H}), 6.96(\mathrm{~m}, 4 \mathrm{H}), 6.26(\mathrm{dt}, J=8,1.5 \mathrm{~Hz}, 2 \mathrm{H}), 6.21$ (s, 2H). FT-IR $(\mathrm{KBr}, v): 845 \mathrm{~cm}^{-1}$.

2.7b Synthesis of $\left[\left\{(p p y)_{2} I r\right\} L_{2}\right]\left(P F_{6}\right)(2):$ A similar procedure as followed for the synthesis of complex 1 was followed here. The crude product was purified by neutral alumina column using $\mathrm{CH}_{2} \mathrm{Cl}_{2}$ as eluent which led to pure 2 . Yield: $50.15(33 \%)$. Molar conductivity $\left[\Lambda_{\mathrm{M}}\left(\Omega^{-1} \mathrm{~cm}^{2} \mathrm{M}^{-1}\right]\right.$ in acetonitrile: 84. A positive ion ESI mass spectrum of $\mathbf{2}$ in $\mathrm{CH}_{3} \mathrm{OH}$ exhibited signal at $\mathrm{m} / z=810$ corresponding to $\left[2-\mathrm{PF}_{6}\right]^{+}$(calculated molecular mass: 810.94). ${ }^{1} \mathrm{H}$ NMR $\left(400 \mathrm{MHz}, \mathrm{DMSO}_{-} \mathrm{d}_{6}\right.$ at $\left.298 \mathrm{~K}\right) \delta 9.22(\mathrm{~d}, J=8.2 \mathrm{~Hz}, 1 \mathrm{H})$, $8.90(\mathrm{~s}, 1 \mathrm{H}), 8.85(\mathrm{~d}, J=8.6 \mathrm{~Hz}, 1 \mathrm{H}), 8.26(\mathrm{dd}, J=12.1$, $8.1 \mathrm{~Hz}, 2 \mathrm{H}), 8.18(\mathrm{~d}, J=5.3 \mathrm{~Hz}, 1 \mathrm{H}), 8.11(\mathrm{~m}, 2 \mathrm{H}), 7.95(\mathrm{~m}$, $3 \mathrm{H}), 7.87(\mathrm{~m}, 2 \mathrm{H}), 7.47(\mathrm{t}, J=7.22 \mathrm{H}), 7.36(\mathrm{~m}, 2 \mathrm{H}), 7.28$ (m, 3H), $7.06(\mathrm{qd}, J=7.5,1.3 \mathrm{~Hz}, 2 \mathrm{H}), 6.97(\mathrm{~m}, 4 \mathrm{H}), 6.26$ (d, $J=7.5 \mathrm{~Hz}, 2 \mathrm{H}), 6.14$ (s, 2H). FT-IR (KBr, v): $845 \mathrm{~cm}^{-1}$.

2.7c Synthesis of $\left[\left\{(p p y)_{2} I r\right\} L_{3}\right]\left(P F_{6}\right)(3)$ : Procedure followed was same as for the synthesis of complex 1. The crude product was purified by neutral alumina column using $\mathrm{CH}_{2} \mathrm{Cl}_{2}: \mathrm{CH}_{3} \mathrm{OH}$ (50:1) as eluent. Yield: $70.8 \mathrm{mg}$ (46\%). Molar conductivity $\left[\Lambda_{\mathrm{M}} /\left(\Omega^{-1} \mathrm{~cm}^{2} \mathrm{M}^{-1}\right)\right]$ in acetonitrile: 82. A positive ion ESI mass spectrum of $\mathbf{3}$ in $\mathrm{CH}_{3} \mathrm{OH}$ exhibited signal at $m / z=816$ corresponding to $\left[3-\mathrm{PF}_{6}\right]^{+}$ (calculated molecular mass: 816.99). ${ }^{1} \mathrm{H}$ NMR $(400 \mathrm{MHz}$, DMSO-d $_{6}$ at $\left.298 \mathrm{~K}\right) \delta 9.17(\mathrm{dd}, J=8.3,1.3 \mathrm{~Hz}, 1 \mathrm{H}), 9.03$ $(\mathrm{d}, J=9.5 \mathrm{~Hz}, 1 \mathrm{H}), 8.68(\mathrm{~s}, 1 \mathrm{H}), 8.27(\mathrm{~d}, J=8.3 \mathrm{~Hz}$, $2 \mathrm{H}), 8.21(\mathrm{~d}, J=5.4 \mathrm{~Hz}, 1 \mathrm{H}), 8.17(\mathrm{~d}, J=4.8 \mathrm{~Hz}, 1 \mathrm{H})$, 8.10 (ddd, $J=18.6,8.3,5.0 \mathrm{~Hz}, 2 \mathrm{H}), 7.96(\mathrm{~d}, J=7.6 \mathrm{~Hz}$, $2 \mathrm{H}), 7.89(\mathrm{~m}, 2 \mathrm{H}), 7.50(\mathrm{dd}, J=11.7,5.6 \mathrm{~Hz}, 2 \mathrm{H}), 7.07(\mathrm{t}$, $J=7.5 \mathrm{~Hz}, 2 \mathrm{H}), 6.98(\mathrm{~m}, 4 \mathrm{H}), 6.29(\mathrm{t}, J=7.36 \mathrm{~Hz}, 2 \mathrm{H})$, $4.65(\mathrm{~d}, J=6.4 \mathrm{~Hz}, 2 \mathrm{H}), 1.91(\mathrm{~m}, 1 \mathrm{H}), 1.69(\mathrm{~d}, J=6.8 \mathrm{~Hz}$, $3 \mathrm{H}), 1.62(\mathrm{~d}, J=9.9 \mathrm{~Hz}, 2 \mathrm{H}), 1.15(\mathrm{~m}, 5 \mathrm{H})$. FT-IR $(\mathrm{KBr}, v)$ : $845 \mathrm{~cm}^{-1}$.

\section{Results and Discussion}

\subsection{Synthesis and characterization}

The ligands $\mathbf{L}_{1}-\mathbf{L}_{3}$ were prepared by following the procedure outlined in Scheme S1 (in Supplementary Information) ${ }^{37}$ The pure ligands $\left(\mathbf{L}_{1}-\mathbf{L}_{3}\right)$ were obtained by the reaction of $1 \mathrm{H}$-imidazo[4,5-f][1,10]phenanthroline with corresponding halide (1:1.2 molar ratio) in the presence of $\mathrm{K}_{2} \mathrm{CO}_{3}$ in dry DMF under $\mathrm{N}_{2}$ atmosphere at room temperature. The formation of pure ligands $\left(\mathbf{L}_{1}-\right.$ $\mathbf{L}_{3}$ ) was confirmed by ${ }^{1} \mathrm{H}$ NMR spectroscopy (Figure S1 in Supplementary Information). It is to be noted that the ligands $\mathbf{L}_{1}$ and $\mathbf{L}_{3}$ are new and their metallation is yet to be reported.

The mononuclear iridium complexes 1-3 were prepared by reacting the ligands $\left(\mathbf{L}_{1}-\mathbf{L}_{3}\right)$ with dimeric precursor $\left[(\text { ppy })_{2} \operatorname{Ir}(\mu-\mathrm{Cl})\right]_{2}$ in an appropriate ratio in 2methoxyethanol under a dinitrogen atmosphere for $12 \mathrm{~h}$ (Scheme 1). The pure complexes were isolated as their $\mathrm{PF}_{6}^{-}$salts. All the complexes behaved as 1:1 electrolyte in $\mathrm{CH}_{3} \mathrm{CN}$. The presence of $\mathrm{PF}_{6}^{-}$counter anion in the complexes was evidenced by observing characteristic IR vibration at $845 \mathrm{~cm}^{-1}$.

The ${ }^{1} \mathrm{H}$ NMR spectra of the complexes (1-3) were recorded in DMSO- $\mathrm{d}_{6}$ (Figure S2 in Supplementary Information). All the complexes exhibited expected the number of proton resonance within the chemical shift range $0-10 \mathrm{ppm}$ indicating the presence of ppy and imidazole-based ligands $\left(\mathbf{L}_{1}-\mathbf{L}_{3}\right)$ and their identities in solution. 


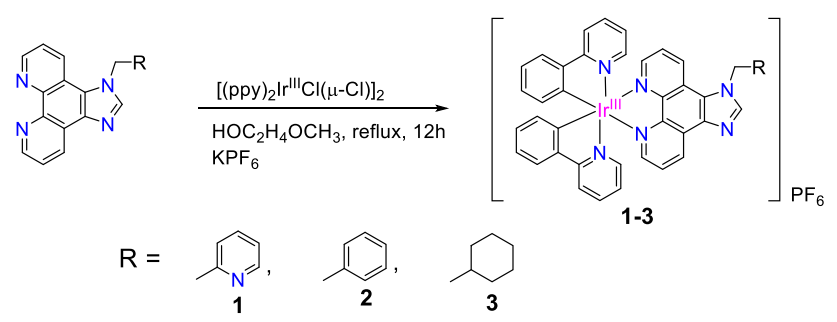

Scheme 1. Synthetic outline for the preparation of complexes 1-3.
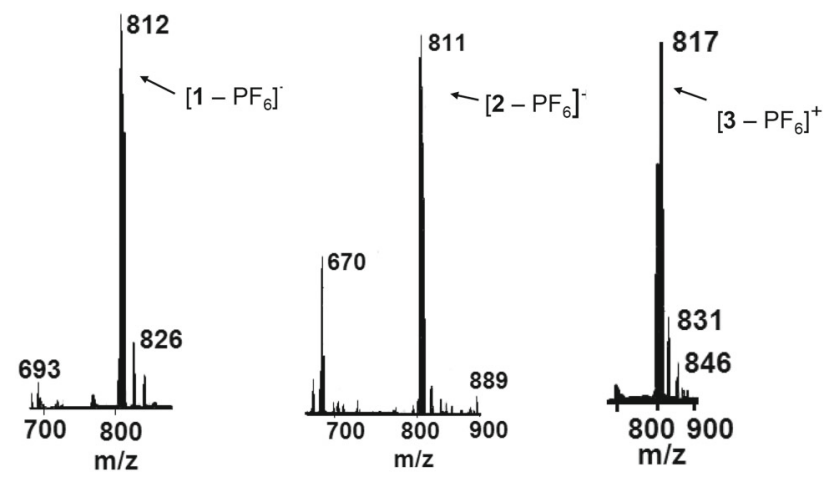

Figure 1. Positive ion ESI mass spectra of the complexes 1-3 in $\mathrm{CH}_{3} \mathrm{OH}$.

The formation of complexes was confirmed by their positive ion electrospray mass spectrometry (Figure 1). In $\mathrm{CH}_{3} \mathrm{OH}$ the complexes displayed molecular ion peaks centered at 812.0 for $\left\{\mathbf{1}-\mathrm{PF}_{6}\right\}^{+}$(Calcd. 811.94), 811 for $\left\{\mathbf{2}-\mathrm{PF}_{6}\right\}^{+}$(Calcd. 810.95), and 817.0 for $\left\{\mathbf{3}-\mathrm{PF}_{6}\right\}^{+}$ (Calcd. 816.99) confirming the presence of their entire molecular frameworks.

Figure 2(a) displays the UV-Vis spectra of the complexes recorded in $\mathrm{CH}_{3} \mathrm{CN}$. The complexes exhibited ligand-based transitions $\left(\pi \rightarrow \pi^{*}\right)$ in the high energy UV region $(<300 \mathrm{~nm})$ and low energy metal-to-ligand charge transfer transitions (MLCT) in the visible regions $(>350 \mathrm{~nm})$ (Table S1 in Supplementary Information). The shorter wavelength transitions with high extinction coefficient were assigned as spin-allowed ligand-based $\left(\pi \rightarrow \pi^{*}\right)$ transitions from ppy and $\mathbf{L}_{1}-\mathbf{L}_{3}$ ligands. ${ }^{38-40}$ While the longer wavelength absorption shoulders above $400 \mathrm{~nm}$ might be assigned as an admixture of spin-allowed metal-to-ligand charge-transfer $\left({ }^{1} \mathrm{MLCT}\right.$ : $\left.\mathrm{d} \pi \rightarrow \pi *_{\text {phen }}\right)$ and ligand-to-ligand charge transfer $\left({ }^{1}\right.$ LLCT $\left.: \pi_{\text {ppy }} \rightarrow \pi *_{\text {phen }}\right)$ processes. ${ }^{3,41-45}$ The very low-intensity band observed in the range 400-500 nm (Figure 2(a)) might be assigned as spin-forbidden ${ }^{3}$ MLCT and ${ }^{3}$ LLCT transitions. This observation is not consistent with the similarly reported complexes. ${ }^{3,42-47}$ No noticeable changes in band position were observed for the complexes indicating that the substituents at the
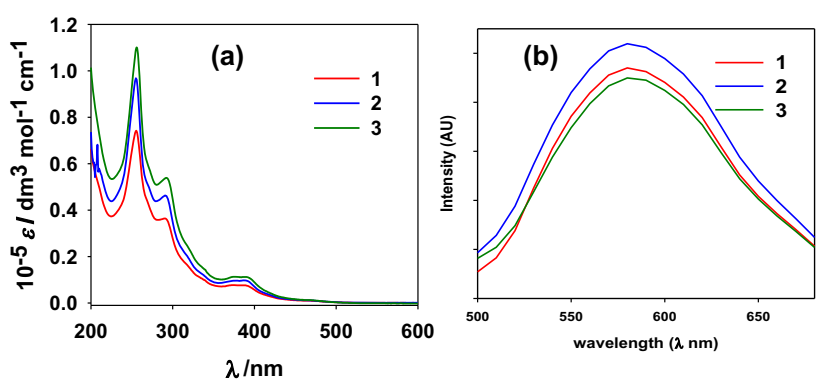

Figure 2. (a) UV-Vis and (b) emission spectra of the complexes 1-3 recorded in $\mathrm{CH}_{3} \mathrm{CN}$.

imidazo end have a negligible or no effect on the metal centres.

The complexes 1-3 were found to be luminescent (Figure 2(b)). The emission behaviour of cyclometallated iridium complexes were studied in $\mathrm{CH}_{3} \mathrm{CN}$. It was observed that upon photoexcitation of the complexes at $390 \mathrm{~nm}$ exhibited emission band at $580 \mathrm{~nm}$ with a quantum yield of 0.07 , with reference to the standard $\left[\mathrm{Ru}(\mathrm{bpy})_{3}\right] \mathrm{Cl}_{2} \cdot{ }^{27,48}$ Such transitions generally appeared from the ${ }^{3} \mathrm{MLCT}(\mathrm{d} \pi(\mathrm{Ir}) \rightarrow \pi *$ (imidazole)) excited state. ${ }^{27,34}$

The electrochemical behaviour of the complexes (13) was studied in $\mathrm{CH}_{3} \mathrm{CN}$ at room temperature using $\mathrm{Ag} / \mathrm{AgCl}$ reference electrode and glassy carbon working electrode. All the complexes showed metal-based quasireversible redox couple $\left(\mathrm{Ir}^{\mathrm{IV}} / \mathrm{Ir}^{\mathrm{III}}\right)$ at $\sim 1.25 \mathrm{~V}$ (Table $\mathrm{S} 1$ in Supplementary Information). No significant shift in the oxidation potential of the metal centres was observed indicating no or negligible electronic contribution from the substituents present in the imidazole moiety, which is consistent with the results observed in UV-Vis spectroscopy. The ligand-based reductions were observed at the negative potential in the cyclic voltammograms.

\subsection{Biological activity study}

Cyclometallated iridium complexes are known to exhibit anticancer activity. The cytotoxicity of the complexes 1-3 were tested against human breast cancer cell line (MCF-7) by standard 3-(4,5-dimethylthiazol-2-yl)2,5-diphenyl-tetrazolium bromide (MTT) assay. The formation of formazan due to the reduction of tetrazole of MTT by mitochondrial dehydrogenases in the living cells was quantified at $595 \mathrm{~nm}$. The complexes were found to show dose-dependent suppression of cell viability towards the tested cancer (MCF-7) cell line and better activity than standard cisplatin (Figure 3, Table 1). Results reveal that anticancer activity of the complexes $2 / 3$ ( $_{50}$ values $1.5 \mu \mathrm{M}$ for 2 and $2.5 \mu \mathrm{M}$ for $\mathbf{3}$ ) were better than for $\mathbf{1}\left(\mathrm{IC}_{50} \sim 20.7 \mu \mathrm{M}\right)$. 


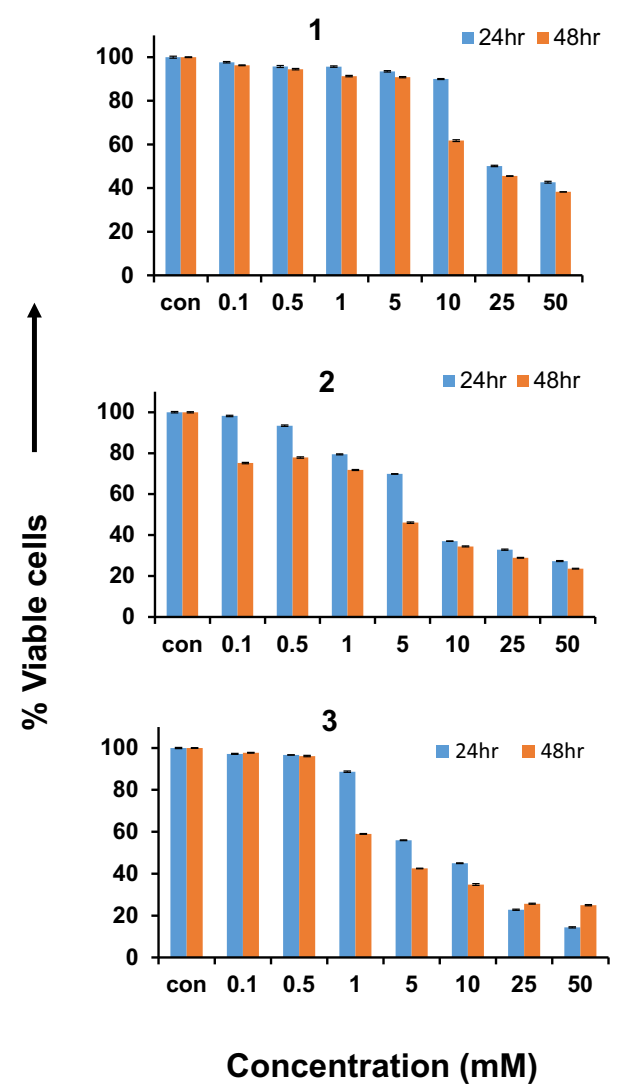

Figure 3. Dose-dependent suppression of cell viability of complexes $\mathbf{1 - 3}$ towards human breast (MCF-7) cancer cells.

Table 1. Lipophilicity of the complexes 1-3 and in vitro growth inhibition against human breast cancer (MCF-7) cells. $\mathrm{P}_{\mathrm{o} / \mathrm{w}}$ is the dimensionless partition coefficient of the complexes in octanol/water solvent system.

\begin{tabular}{lllr}
\hline Complex & $\log \mathrm{P}_{\mathrm{o} / \mathrm{w}}$ & \multicolumn{2}{l}{$\mathrm{IC}_{50}(\mu \mathrm{M})$} \\
\cline { 3 - 4 } & & $24 \mathrm{~h}$ & $48 \mathrm{~h}$ \\
\hline $\mathbf{1}$ & 2.45 & 25.4 & 20.7 \\
$\mathbf{2}$ & 2.75 & 5.3 & 1.5 \\
$\mathbf{3}$ & 3.2 & 7.2 & 2.5 \\
Cisplatin & & - & 35.6 \\
\hline
\end{tabular}

To further understand the anticancer activity of $\mathbf{2 / 3}$ over 1, we conducted a cellular uptake study using hydrophobicity measurement. Hydrophobicity value often provides indirect measure of cellular uptake. It was observed that the hydrophobicity values of complexes $\mathbf{2 / 3}$ were a little higher as compared to $\mathbf{1}$ which may contribute better uptake of former complexes than latter. To further understand the varying anticancer activity

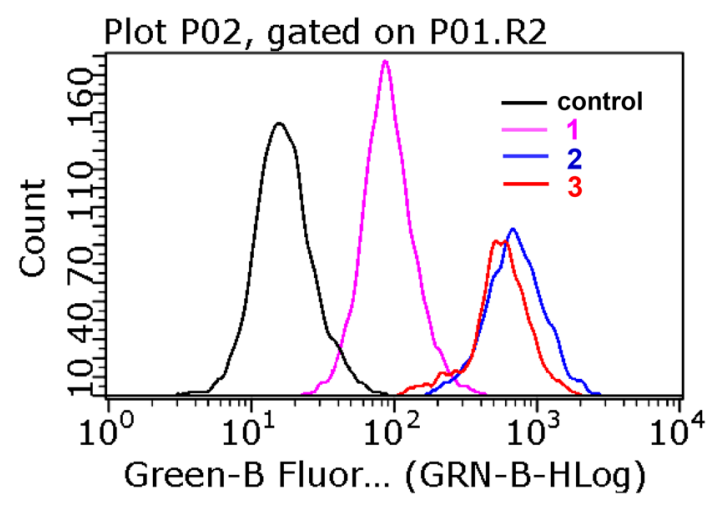

Figure 4. Flow cytometry analysis results of MCF-7 cells incubated with blank medium (control) and complexes $\mathbf{1 - 3}(10 \mu \mathrm{M})$ at $37^{\circ} \mathrm{C}$ for $3 \mathrm{~h}$. (excitation, $530 \mathrm{~nm}$; emission, $585 \mathrm{~nm}$ ).
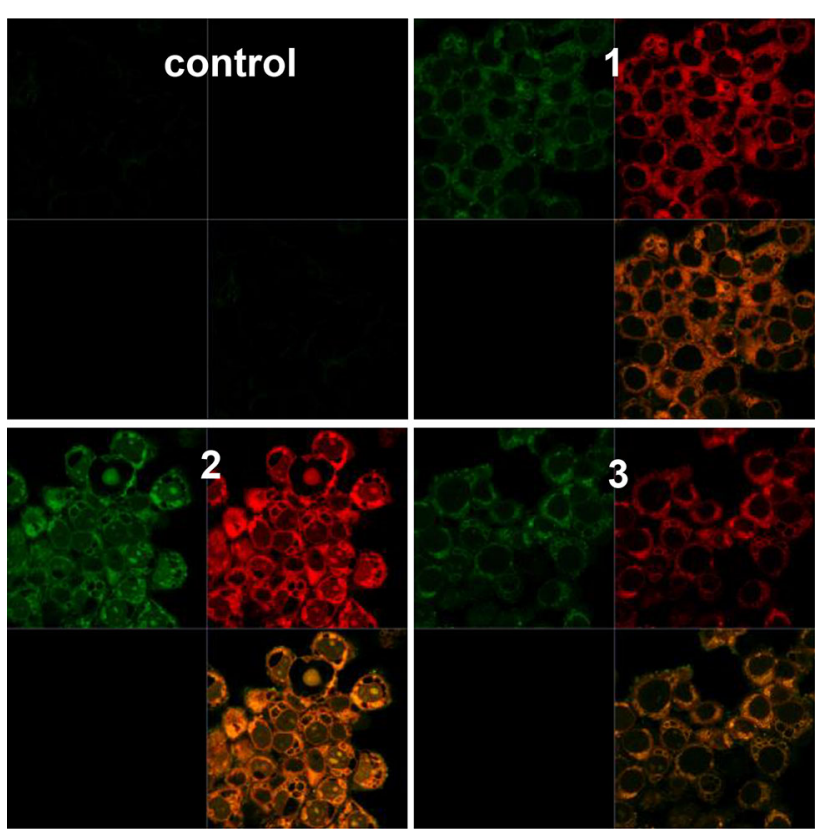

Figure 5. Fluorescence microscopic images (magnification 400x) of human breast cancer cells (MCF7) treated with or without treatment of $10 \mu \mathrm{M}$ complexes 1-3. The images were recorded $24 \mathrm{~h}$ after the treatment of the complexes.

of the complexes, we conducted flow cytometry analysis. It was observed that the cellular uptake of $\mathbf{2 / 3}$ was much higher than 1 (Figure 4), which corroborates the observed anticancer activity. We next recorded the fluorescence microscopy images of MCF-7 cells treated with complexes which are emissive (Figure 5). The fluorescence microscopy images of MCF-7 cells treated by complexes demonstrated good cellular accumulation inside the cells. It was also observed that the complexes were distributed well throughout the cells. Thus, the combined results suggest that the anticancer activity of the present set of complexes is mainly dependent on the cellular uptake. Although not significant, the distal 
components (N-substituents of imidazole unit) of $\mathbf{L}_{1}-\mathbf{L}_{3}$ such as phenyl/pyridine/cyclohexyl also play an important role to control the hydrophobicity and thereby the anticancer activity.

\section{Conclusions}

Cyclometallated iridium complexes (1-3) using imidazo-phenanthroline based ligands $\left(\mathbf{L}_{1}-\mathbf{L}_{3}\right)$ were synthesized. The complexes were characterized by various analytical techniques. The anticancer activity of the complexes against human breast cancer cell line (MCF7) was tested. The complexes were found to be highly active. The flow cytometry and hydrophobicity analyses result revealed that better cellular uptake is primarily responsible for the variation in anticancer activities. The iridium centre in a combination of ppy and ligand $\mathbf{L}_{3}$ having cyclohexyl group at the imidazole end is found to be suitable to achieve desired anticancer activity. We believe that the present set of complexes would be useful for the design and development of efficient anticancer agents via suitable variation of substituents both at the ppy and pyrazine-based ligands.

\section{Supplementary Information (SI)}

Synthetic scheme for ligands, NMR spectra of ligands and complexes, spectra and electrochemical data are available as Electronic Supplementary Information at www.ias.ac.in/ chemsci.

\section{Acknowledgements}

The authors are thankful to the Science and Engineering Research Board (SERB) Government of India, (EMR/2015/ 002219), for financial support. The authors also acknowledge Dr. A. L. Koner for his kind help in recording ESI mass spectra of the complexes.

\section{References}

1. Wilbuer A, Vlecken D H, Schmitz D J, Kraeling K, Harms K, Bagowski C P and Meggers E 2010 Iridium Complex with Antiangiogenic Properties Angew. Chem. Int. Ed. 493839

2. Leung C H, Zhong H J, Chan D S H and Ma D L 2013 Bioactive Iridium and Rhodium Complexes as Therapeutic Agents Coord. Chem. Rev. 2571764

3. Tripathy S K, De U, Dehury N, Pal S, Kim H S and Patra S 2014 Dinuclear $[(\mathrm{p}$-cym $) \mathrm{RuCl} 2(\mu$-phpy $)](\mathrm{PF} 6) 2$ and Heterodinuclear [(ppy) $2 \operatorname{Ir}(\mu$-phpy $) \operatorname{Ru}(\mathrm{p}-$ cym)Cl](PF6)2 Complexes: Synthesis, Structure and Anticancer Activity Dalton Trans. 4314546
4. He L, Liao S Y, Tan C P, Lu Y Y, Xu C X, Ji L N and Mao Z W 2014 Cyclometalated Iridium(iii)$\beta$-Carboline Complexes as Potent Autophagy-Inducing Agents Chem. Commun. 505611

5. Blanck S, Geisselbrecht Y, Kräling K, Middel S, Mietke T, HarmsK, Essen L O and Meggers E 2012 Bioactive Cyclometalated Phthalimides: Design, Synthesis and Kinase Inhibition Dalton Trans. 419337

6. Leung $\mathrm{C} \mathrm{H}$, Zhong H J, Yang H, Cheng Z, Chan D S H, Ma V P Y, Abagyan R, Wong C Y and Ma D L 2012 A Metal-Based Inhibitor of Tumor Necrosis Factora Angew. Chem. Int. Ed. 519010

7. Zhong H J, Leung K H, Liu L J, Lu L, Chan D S H, Leung C H and Ma D L 2014 Antagonism of mTOR Activity by a Kinetically Inert Rhodium(III) Complex ChemPlusChem 79508

8. Tripathy S K, De U, Dehury N, Laha P, Panda M K, Kim H S and Patra S 2016 Cyclometallated Iridium Complexes Inducing Paraptotic Cell Death like Natural Products: Synthesis, Structure and Mechanistic Aspects Dalton Trans. 4515122

9. Tripathy S K, Surada R K, Manne R K, Mobin S M, Santra M K and Patra S 2013 Synthesis, Characterisation and Biological Activities of $[(\mathrm{P}-\mathrm{cym}) \mathrm{RuX}(\mathrm{pz} 4 \mathrm{lut})] \mathrm{n}+$ and $[(\mathrm{p}-\mathrm{cym}) \mathrm{RuX} 2(\mu-\mathrm{pz} 4 \mathrm{lut})] \mathrm{n}+(\mathrm{X}=\mathrm{Cl}, \mathrm{H} 2 \mathrm{O}$ and pz4lut $=\mathrm{A}, \alpha, \alpha^{\prime}, \alpha^{\prime}$-Tetra(pyrazol-1-Yl)- 2,6-Lutidine) Dalton Trans. 4214081

10. Li S P Y, Tang T S M, Yiu K S M and Lo K K W 2012 Cyclometalated Iridium(III)-Polyamine Complexes with Intense and Long-Lived Multicolor Phosphorescence: Synthesis, Crystal Structure, Photophysical Behavior, Cellular Uptake, and Transfection Properties Chem. Eur. J. 1813342

11. Leung K H, He H Z, Ma V P Y, Chan D S H, Leung C H and Ma D L 2013 A Luminescent G-Quadruplex Switch-on Probe for the Highly Selective and Tunable Detection of Cysteine and Glutathione Chem. Commun. 49771

12. Shi C, Sun H, Tang X, Wen L, Yan H, Zhao Q, Wang J and Huang W 2013 Variable Photophysical Properties of Phosphorescent Iridium(III) Complexes Triggered by Closo - and Nido-Carborane Substitution Angew. Chem. Int. Ed. $\mathbf{5 2} 13434$

13. Zhou Y, Jia J, Li W, Fei H and Zhou M 2013 Luminescent Biscarbene Iridium(iii) Complexes as Living Cell Imaging Reagents Chem. Commun. 493230

14. Zhang G, Zhang H, Gao Y, Tao R, Xin L, Yi J, Li F, Liu W and Qiao J 2014 Near-Infrared-Emitting Iridium(III) Complexes as Phosphorescent Dyes for Live Cell Imaging Organometallics $\mathbf{3 3} 61$

15. Lo K K W 2015 Luminescent Rhenium(I) and Iridium(III) Polypyridine Complexes as Biological Probes, Imaging Reagents, and Photocytotoxic Agents Acc. Chem. Res. 482985

16. Chen Z, Zhang K Y, Tong X, Liu Y, Hu C, Liu S, Yu Q, Zhao Q and Huang W 2016 Phosphorescent Polymeric Thermometers for In Vitro and In Vivo Temperature Sensing with Minimized Background Interference $A d v$. Funct. Mater. 264386

17. Zhang K Y, Liu H W, Tang M C, Choi A W T C A, Zhu N, Wei X G, Lau K C and Lo K K W 2015 Dual-Emissive Cyclometalated Iridium(III) Polypyridine Complexes as 
Ratiometric Biological Probes and Organelle-Selective Bioimaging Reagents Inorg. Chem. 546582

18. Omae I 2014 Applications of Five-Membered Ring Products of Cyclometalation Reactions as Anticancer Agents Coord. Chem. Rev. 28084

19. Liu L J, Lu L, Zhong H J, He B, Kwong D W J, Ma D L and Leung C H 2015 An Iridium(III) Complex Inhibits JMJD2 Activities and Acts as a Potential Epigenetic Modulator J. Med. Chem. 586697

20. Xue F, Lu Y, Zhou Z, Shi M, Yan Y, Yang H and Yang S 2015 Two in One: Luminescence Imaging and $730 \mathrm{Nm}$ Continuous Wave Laser-Driven Photodynamic Therapy of Iridium Complexes Organometallics 3473

21. Cao J J, Tan C P, Chen M H, Wu N, Yao D Y, Liu X G, Ji L N and Mao Z W 2017 Targeting Cancer Cell Metabolism with Mitochondria-Immobilized Phosphorescent Cyclometalated Iridium(Iii) Complexes Chem. Sci. 8631

22. Liu H, Gao H, Zhao Y and Shen Z 2017 Synthesis and Photophysical Properties of Cyclometalated Heteroleptic iridium(III) Complexes Containing Pyridyl/isoquinolyl-Imino-Isoindoline Ancillary Ligand Supramol. Chem. 1

23. Salvadó I, Gamba I, Montenegro J, Martínez-Costas J, Brea J M, Loza I M, López M V and Vázquez M E 2016 Membrane-Disrupting iridium(III) Oligocationic Organometallopeptides Chem. Commun. 5211008

24. Ye R R, Tan C P, Ji L N and Mao Z W 2016 CoumarinAppended Phosphorescent Cyclometalated Iridium(III) Complexes as Mitochondria-Targeted Theranostic Anticancer Agents Dalton Trans. 4513042

25. Zhou Y, Jia J, Wang X, Guo W, Wu Z and Xu N 2016 Protein Staining Agents from Cationic and Neutral Luminescent Iridium(III) Complexes Chem. Eur. J. 2216796

26. Dehury N, Maity N, Tripathy S K, Basset J M and Patra S 2016 Dinuclear Tetrapyrazolyl Palladium Complexes Exhibiting Facile Tandem Transfer Hydrogenation/Suzuki Coupling Reaction of Fluoroarylketone ACS Catal. 65535

27. Li C, Yu M, Sun Y, Wu Y, Huang C and Li F 2011 A Nonemissive Iridium(III) Complex That Specifically Lights-Up the Nuclei of Living Cells J. Am. Chem. Soc. 13311231

28. Liu Z, Habtemariam A, Pizarro A M, Clarkson G J and Sadler P J 2011 Organometallic iridium(III) Cyclopentadienyl Anticancer Complexes Containing C, N-Chelating Ligands Organometallics 304702

29. Park H J and Chung Y K 2012 Ru(II)-M(I) (M=Rh and Ir) Bimetallic Complexes Based on a Bridging Ligand Composed of 1,10-Phenanthroline and N-Heterocyclic Carbene: Coordination Chemistry and Detection Property of Carbon Monoxide Inorg. Chim. Acta 391105

30. Park H J, Kim K and Chung Y K 2014 ReI-IrI Bimetallic Complexes Based on a Bis(chelating) Ligand Composed of 1,10-Phenanthroline and N-Heterocyclic Carbene: Coordination Chemistry and Their Application for Optical Indicator of CO Gas Inorg. Chim. Acta 410 214

31. Qiu K, Liu Y, Huang H, Liu C, Zhu H, Chen Y, Ji L and Chao H 2016 Biscylometalated Iridium(Iii) Complexes Target Mitochondria or Lysosomes by Regulating the Lipophilicity of the Main Ligands Dalton Trans. 45 16144

32. Jin C, Liu J, Chen Y, Zeng L, Guan R, Ouyang C, Ji L and Chao H 2015 Cyclometalated Iridium(III) Complexes as Two-Photon Phosphorescent Probes for Specific Mitochondrial Dynamics Tracking in Living Cells Chem. Eur. J. 2112000

33. Peuntinger K, Pilz T D, Staehle R, Schaub M, Kaufhold S, Petermann L, Wunderlin M, Görls H, Heinemann F W, Li J, Drewello T, Vos J G, Guldi D M and Rau S 2014 Carbene Based Photochemical Molecular Assemblies for Solar Driven Hydrogen Generation Dalton Trans. 43 13683

34. Nonoyama M 1974 Benzo[h]quinolin-10-ylNIridium(III) Complexes Bull. Chem. Soc. Jpn. 47767

35. Ghosh A, Mandoli A, Krishna K D, Yadav N S, Ghosh T, Jha B, Thomas J A and Das A 2009 DNA binding and cleavage properties of a newly synthesised $\mathrm{Ru}(\mathrm{II})-$ polypyridyl complex Dalton Trans. 429312

36. Danialsson L and Zhang Y 1996 Methods for Determiningn-Octanol-Water Partition Constants TrAC Trends Anal. Chem. 15188

37. Peuntinger K, Pilz T D, Staehle R, Schaub M, Kaufhold S, Petermann L, Wunderlin M, Görls H, Heinemann F W, Li J, Drewello T, Vos J G Guldi D M and Rau S 2014 Carbene Based Photochemical Molecular Assemblies for Solar Driven Hydrogen Generation Dalton Trans. 43 13683

38. Lee P, Law W H, Liu H and Lo K K W 2011 Luminescent Cyclometalated Iridium (III) Polypyridine Di2- Picolylamine Complexes: Synthesis, Photophysics, Electrochemistry, Cation Binding, Cellular Internalization, and Cytotoxic Activity Inorg. Chem. 508570

39. Donato L, McCusker C E, Castellano F N and ZysmanColman E 2013 Mono- and Dinuclear Cationic Iridium(III) Complexes Bearing a 2,5-Dipyridylpyrazine (2,5-Dpp) Ligand Inorg. Chem. 528495

40. Bura T, Gullo M P, Ventura B, Barbieri A and Ziessel R 2013 Multichromophoric Arrays Arranged around a Triptycene Scaffold: Synthesis and Photophysics Inorg. Chem. 528653

41. Lo S, Shipley C P, Bera R N, Harding R E, Cowley A R, Burn P L, Samuel I D W, Uni V, Haugh N, Andrews S, May R V, Re V, Recei M and July V 2006 Blue Phosphorescence from Iridium (III) Complexes at Room Temperature Chem. Mater. 185119

42. Lo K K W, Li, S P Y and Zhang K Y 2011 Development of Luminescent iridium(III) Polypyridine Complexes as Chemical and Biological Probes New J. Chem 35265

43. Lau J S Y, Lee P K, Tsang K H K, Ng C H C, Lam Y W, Cheng S H and Lo K K W 2009 Luminescent Cyclometalated Iridium(III) Polypyridine Indole Complexes-Synthesis, Photophysics, Electrochemistry, Protein-Binding Properties, Cytotoxicity, and Cellular Uptake Inorg. Chem. 48708

44. Li S P, Liu H, Zhang K Y and Lo K K W 2010 Modification of Luminescent Iridium (III) Polypyridine Complexes with Discrete Poly (Ethylene glycol)(PEG) Pendants: Synthesis, Emissive Behavior, Intracellular Uptake, and PEGylation Properties Chem. Eur. J. 16 8329 
45. Mandal S, Poria D K, Ghosh R, Ray P S and Gupta P 2014 Development of a Cyclometalated Iridium Complex with Specific Intramolecular Hydrogen-Bonding That Acts as a Fluorescent Marker for the Endoplasmic Reticulum and Causes Photoinduced Cell Death Dalton Trans. 4317463

46. Lo K KW, Chung C and Zhu N 2006 Nucleic Acid Intercalators and Avidin Probes Derived from Luminescent Cyclometalated Iridium (III)-dipyridoquinoxaline anddipyridophenazine Complexes Chem. Eur. J. 121500
47. Jin C, Liu J, Chen Y, Li G, Guan R, Zhang P, Ji L and Chao H 2015 Cyclometalated Iridium (III) Complexes with Imidazo [4,5-f] $[1,10]$ Phenanthroline Derivatives for Mitochondrial Imaging in Living Cells Dalton Trans. 44 7538

48. Van Houten J and Watts R J 1978 Photochemistry of tris(2,2'-bipyridyl)ruthenium(II) in Aqueous Solutions Inorg. Chem. 173381 